\title{
An Assessment of E-Payment Infrastructures towards an Efficient Cashless Policy in Nigeria: A Case Study of Bauchi State
}

\author{
${ }^{1}$ Shittu Oladipupo Ibrahim, ${ }^{2}$ Yusuf Bashir Maiwada (Phd) \\ ${ }^{1,2}$ Faculty of Management Technology Accounting And Finance Department Abubukar Tafawa Balewa \\ University, Bauchi
}

\begin{abstract}
The growing rate of trade brings about improvement in the payment system from the trade by barter system era to the unit of weight system of payment, coins and notes to the present electronic payment system. As a result of high cost of cash management among others the government through the Central Bank of Nigeria, implement the cashless policy for the betterment of the economy, but the question remains; do we have the epayment infrastructure for the efficiency of cashless society? The study aim to access e-payment infrastructure towards an efficient cashless policy in Nigeria. Two hundred and fifty (250) questionnaires were distributed to bank customers and two hundred and twenty nine (nine) where returned, tables and percentages where used to make analyses while chi-square statistical method was used to test the hypothesis. It was concluded that effective e-payment infrastructure is an essential tool to achieve an efficient cashless policy in Nigeria. More PoSterminals should be deployed; ATM should properly be managed while government agencies should ensure efficient telecommunication service delivery.
\end{abstract}

Keywords: cashless policy, e-payment, e-payment infrastructure, Point-of-Sale terminals

\section{Introduction}

The increased rate of trade give birth to payment for goods and services as before then trade usually involve the exchange of goods and services which is referred to as barter system (trade by barter). There are lots of constraints during this period as people findit difficult to get their needs exchanged for (that is, double coincidence of want), for example, if someone needsrice but has yam, such person must look for another person that has rice and must be ready to exchange the rice for yam, which makes exchange to be difficult. Quest of solving this problem gives rise to payment system which was initially from units of weight, units of accounts such as cowries, gold, silver, coins; which later transpire into the recent modern banking system. Ever since money was introduced as a means of representing value, system for making payments have been lot easier (Asaolu, Ayoola and Akinkoye, 2011). As population increases, volume of transactions increase locally and even across the globe and with the aid of Information and Communication Technology the system then calls for an efficient way of settling transactions irrespective of location.

There is no doubt that recently the banking industry is going through a tough time in epileptic customer service especially in virtually all e-payment solution platforms. The performances of the financial infrastructures have been seriously hampered as most of them are unable to perform efficiently as there are lot of complaints, queue, and frustrations. ATMs are routinely out of order and out of cash; customers also do complain of their ATM cards being retracted by the machine, in some cases, customers are debited for cash not dispensed and reconciliation take a lot of time to get the transactions reversed or will not even be reversed sometimes. Though, it is not argued that customers can make use of his or her ATM cards on any bank's ATM, but yet some customers prefer to still use their card on the domiciled bank's ATM because of lack of confidence in the efficiency of the e-payment transaction because it is noted that if there is a dispense error, it is easier to be corrected/reversed if it is your bank ATM, otherwise it will take a long time even some customers will just forget about their money due to frustration. Such reversal problem is not limited to ATM but also extended to Internet banking and transaction on mobile banking platform as a result of inefficiency of internet service and mobile/phone network service providers.

A cashless society is a gradual movement of the payment system of an economy from the use of physical cash to a systemic adoption of other non- physical cash mode of payment in settlements of all types of transaction both in the public and private sectors of an economy.

According to CBN cashless society is embarked to

- To drive development of the financial system and the economy as a whole.

- To initiate and commence a radical modernization of our payment system in line with international practices worldwide and to facilitate the realization of the dreams of vision 2020 aiming to list Nigeria by amongst the top 20 economies by year 2020, as an efficient and modern payment system is positively correlated with economic development and a key requirement for economic growth. 
- To reduce the cost of banking services, particularly as it relates to cash delivery management between the $\mathrm{CBN}$ and the banking community.

- To facilitate and drive financial inclusions by providing more transaction efficient options and greater and wider banking services reach to the Nigerian society.

- To improve the effectiveness of monetary policy in managing macro-economic indicators particularly inflation, while driving economic growth simultaneously.

Banks want to satisfy their customers to effect and settle any transaction through virtual banking system, in order to reduce the crowd in the banking hall and to also build excellent confidence in the customers' mind. There is a widespread recognition that this challenge can only be met by strategic building of e-banking infrastructures(Imiefoh, 2012).

There is no doubt in the positive impact of cashless policy on the economy but, do we have the infrastructures that will enhance its efficient service without disappointment. Popoola (2013)emphasised that Provision of uninterrupted power supply remains the most important missing link on our way to economic transformation as well as the need to make internet facility available and affordable in all parts of the country (that is, telecommunication service providers' problem). He further opined that if these are able to be fixed provision of financial services would be very good.

Aggressive infrastructure development is essential for the success of cashless policy in Nigeriaas poor infrastructure could be a stumbling block to the success of the policy in some states. For the cashless policy to work in Nigeria we must be able to attain a certain level of infrastructure with the adoption of the right technology, the policy may not work perfectly well where there is incessant power failure and low level and inefficient Internet connectivity.

The aim of the study is to assess electronic payment infrastructures in order to achieve efficient cashless policy in Nigeria.

\section{Brief Review of Literature}

Payment system is defined by Tan (2004) as a system of exchanging monetary value for the receipt of goods and services. Whereas, Annon (2003) explained that an efficient payment systems rely on non-cash payments, and that an efficient and reliable payment system facilitates economic development (Annon, 2003 cited in Nwaolisa and Kasie (2012).E-payment systems therefore, is referred to the automated processes of exchanging monetary value among parties in business transactions and transmitting this value over the information and communication technology (ICT) networks Ayo and Ukpere (2010).

Payment system that is based on physical cash is characterized with high cost of printing and minting, increased cost of handling cash, stress of moving large volume of cash, risk of being attacked by armed robbers, risk of fire among others, so nations are migrating to electronic payment system.

Zulu (2006) identified the challenges of e-Payment in Africa as inadequate telecommunication infrastructure which include: connectivity failure in telephone lines; low Internet bandwidth; high Internet cost, unavailability of dedicated data service networks and close financial networks as well as frequent power interruption.

Onajite (2013), the Chief Executive Officer and Executive Secretary of the Electronic Payment Providers Association of Nigeria (EPPAN); also emphasized that a robust and scalable telecoms infrastructure will make a success of cashless policy, she further explained that there had been cases where some of the PoS machines were not working as a result of network collapse, which automatically became impossible to carry out financial transactions using the electronic cards on the PoS to pay bills, that is, some e-channels infrastructures are not working fine which will deter the success of cashless policy.

Regardless of the adopted system, the problems militating against e-Payment as listed by Sumanjeet(2009) generally revolve around:

a) Integrity: to ascertain that transmitted financial information is unchanged in transit.

b) Non-repudiation: to ascertain that all parties have non-deniable proof of receipt.

c) Confidentiality: to ascertain that transactions are protected from possible eavesdroppers.

d) Reliability: to ascertain that there is reduced possibility of failure.

e) Authentication: to ascertain that there are reliableproofs of identities of all parties involved.

f) Authorization: to ascertain that individuals are recognized and granted the desired rights and privileges. Therefore, any reliable e-Payment system should guarantee privacy, integrity, compatibility, efficiency, acceptability, convenience, mobility, anonymity and low financial risk.

An efficient e-payment infrastructure is then a necessary component of electronic banking, as it forms the essential back bone upon which financial solutions and services transmit and process payment instructions to effect transfers of monetary value among transacting parties. Electronic payment infrastructure in the context of this study is referred to as those facilities and/or platform that enhance or facilitates the workability of e- 
payment system, that are not limited to electricity supply, internet facilities and connectivity, mobile phones and connectivity, PoS, ATM and e-cards (debit card, credit card and e-purse/e-wallet).

\section{Cashless Policy in Nigeria}

The Central Bank of Nigeria (CBN) started the implementation of the cash-less policy using Lagos, the financial and commercial hub of Nigeria, as a pilot scheme. The second phase of the cash-less policy started in July, 2013 with Abuja the Federal Capital Territory(FCT) and five more states.

At the inception of the roll out of the policy, Central Bank of Nigeria set limitsof deposit or withdrawal of cash to both individual and corporate entity, above which penalty will be paid, just to minimize cash handling cost among others and to encourage cashless society.

Nigerians both individual and corporate bodies willpay penalties both for withdrawal and deposit of money into deposit money banks beyond the set limits. A cumulative daily limit of a maximum of Five Hundred Thousand Naira $(\$ 500,000)$ for individuals; and ThreeMillion Naira $(\$ 3,000,000)$, for corporate bodies respectively, were set for both deposits and withdrawals.For individuals, $3 \%$ over the limit is to be charged on withdrawals while $2 \%$ over the limit is to be charged on deposit. For corporate bodies, $5 \%$ over the limit is to be charged on withdrawal while $3 \%$ over the limit is to be charged on deposit.

Implementation of the policy was proposed, to be in phases and was started in Lagos State with the cash limits commencing $1^{\text {st }}$ January, 2012 and the imposition of penalties in Lagos State commencing at the end of March, 2012. The implementation of the second phasecommenced in Abia, Anambra, Kano, Ogun, Rivers states and Abuja on July $1^{\text {st }}, 2013$.

The main focus of the cashless Nigeria project is to reduce (not eliminate) the use of cash to the barest minimum in the entirepayment and settlement systems critical to the intermediate on function of the financial system to facilitate efficient economic growth and development, replacing same with other non-cashpayment and settlement methods for both local and international commercial activities, electronics mode of payment through computer networks and internet system with local and shared interbank service networks through coordinated linkages, that helps to reduce investment in infrastructural facilities and human capital investment needs, were to be the anticipated structural and foundation benefits (Alawiye-Adams, 2013).

Sanusi, who was represented by EmeEleonu, director shared services, CBN, explained at the campaign on cashless policy with the market men and women as well as the entrepreneurs under the Abeokuta Chamber of Commerce, Industry, Mines and Agriculture (ABEOCCIMA), that apart from changing Nigerians' old financial habits to banking and electronic transactions, the electronically-based cashless policy would also employ millions of Nigerians when fully operational, adding that Nigeria could leverage on the policy to gain value for naira and improve on her economy.He revealed that the cashless policy absorbed about 59,596 mobile money agents in December, 2013, just as he added that 256,467 transactions, running to N3.6 billion was recorded through PoS; N202.4 billion recorded from 288,380 transactions on Nigeria electronic fund transfer, while Nigeria inter-bank transfer operations recorded N298.6 billion from 456,488 transactions, all within December, 2013.

From the Central Bank's point of view, the following benefits are expected to be derived by various stakeholders from an increased utilization of e-payment systems:-

For consumers

- Increased convenience, more service options, reduced risk of cash related crimes, cheaper access to (out of branch) banking services and access to credit.

For corporations

- Faster access to capital, reduced revenue leakage and reduced cash handling costs.

For governments

- Increased tax collections, greater financial inclusion, increased economic development even when governments are exempted from the cashless policy implementation, it is still desirous of its increased revenue potentials.

They (CBN) and other financial analyst also emphasise on other motives of the policy as follows:

To stem high cost of cash handling

- There is a high cost of producing and managing cash along the value chain from the CBN and the banks, to corporations, traders which they claim needs to be reduced; everyone within the chain bears the high costs associated with volume cash handling.

To reduce high cost of cash handling

- Cash carrying encourages robberies, thefts and other cash related crimes. It can also lead to colossal losses in the case of fire, and flooding incidents in cash storage and management centers within the chain.

High subsidy in cash management 
- Central Bank analysis showed that only 10 percent of daily banking transactions are above N150,000 but the $10 \%$ account for majority of the high value transactions. This suggests that the entire $90 \%$ volume of lower value banking transactions by the majority subsidizes the costs that the tiny minority $10 \%$ incurs in terms of high costs of cash usage. In other words, it is the poor majority in the economy, that moves the $90 \%$ volume of cash in their little transactions in cash movements that bear the burden of subsidizing the high cost of cash management moving the higher value cash transaction and movements by the minority $10 \%$ of the business and commercial population in transactions in and out of Nigeria.

Need to spread further the larger proportion of funds remaining outside the formal banking system; needs to be captured and recycled back into the formal banking system

- Successive research on the proportion of money in and out of the formal economy, have over time emphasized that only a meager $35 \%$ of the financial resources circulating in Nigeria are resident within the formal banking system, the remaining $65 \%$ of resources are kept and circulated within the informal system, making it continually difficult for the financial system to account accurately for the amount of financial resources within the Nigerian economic system, for the purposes of, monetary policy regulatory controls and for economic development purposes. This funds outside the formal system, limits the effectiveness of monetary policy in managing inflation and encouraging economic growth.

\section{Curbing inefficiency $\&$ corrupt practices}

- High cash usage enables corruption to thrive, through multiple systemic leakages, money laundering among other related fraudulent practices.

Electronic Payment Infrastructures and Cashless Policy in Nigeria

Electronic Payments System has greatly improved financial services, increased banks profitability and enhanced better customer service and has helped to reduce the banking fraud (Adena\&Otaigbe, 2004). The cashless policy was primarily aimed at enthroning electronic payment and the success of a country's payments system is evinced by perceptions of its security, robustness and assessable payment infrastructure (Sanusi, 2013). As described above, electronic payment infrastructures are those facilities deployeddeployed to enhance or facilitates the workability of e-payment system, they are not limited to electricity supply, internet facilities and connectivity, mobile phones and connectivity, PoS, ATM and e-cards (debit card, credit card and e-purse/ewallet).

\section{Electricity Supply}

Electricity as a source of energy has been insufficient in Nigeria which makes lot of Nigerians to be on black out most days. It affects the day-to-day activities of citizens as well as electronic payment system. Most banks and other financial institutions survive on generators to be able to deliver their service to diligently which increases cost reduces profitability. Most telecommunication gadget use for e-payment transactions rely on electricity for charging and which its insufficient leads to e-payment inefficient.

Internet and Mobile Banking facilities and connectivity

Internet and mobile banking success lies on telecommunications service providers, there are good numbers of them in Nigeria, but the question remains; are they efficient? Customers complain almost every day on the inefficiency of mobile and internet service providers in terms of network fluctuations or no network coverage which hinders e-payment system efficiency.

\section{Automated Teller Machine (ATM)}

This is a computerized telecommunications device that provides customers an access to his or her account within the bank which the account is domiciled or other banks. Automated Teller Machine accepts a wide range of command to perform banking services. ATM can be on-site or off-site. On-site ATM are those ATM's that that located within the bank premises while off-site ATM are those that are situated outside the premises of the bank to enhance easy accessibility by customers. Recently customers can use the ATM of any banks without any charges unlike before that they charge off-us fees. ATM is the most widely use e-payment instrument in Nigeria. It is responsible for about 89\% (in volume) of all e-Payment instruments since 2006 to 2008 (Ayo \&Ukpere, 2010).

\section{Point of Sale (PoS) terminal}

A Point of Sale terminal (PoS) is an electronic device used to process card payments at retail locations. It reads card information and it process payment on that card for the transaction effected immediately. This is an important infrastructure for an effective e-payment system and will enhance efficient cashless policy. Electronic Cards 
These are cards that have all the customers' information which are used for transaction any time they are needed. It could be credit card or debit card. Credit cards are plastic cards encoded with electromagnetic identification; it is incorporated with circuit on which value is loaded.it can be used by customers to perform transactions on ATMs by the issuing banks at strategic locations as well as point of sale terminalswith designated signs of the producer of such card. It is preloaded with money. It is like a credit giving to customers by his bank.Debit card on the other hand is an electronic card with very advanced feature including the use of microchip, whereby transaction is validated against the chip rather than a magnetic stripe. It enables the holder to make withdrawals and purchases charged directly to funds in his/her account and your money is immediately deducted from your account when used.

\section{Methodology}

The descriptive survey is adopted in carrying out this research and its success was based on the administration of questionnaire. The population covers banks in Bauchi city numbering 20. A total of two hundred and fifty (250) questionnaires were distributed to the sampled banks' customers selected at random. Respondents' responses were analysed using frequency distribution and percentages while chi-square was used to test the hypothesis.

\section{Data Presentation, Analysis And Hypothesis Testing}

Two sets of questionnaires were administered, one to the marketing/customer care unit staff of the five selected banks and the other one to the customers of the same five selected banks.

Table 1: Analysis of Questionnaires Administered to Banks' Customers

\begin{tabular}{llll}
\hline & Q. Administered & Returned & Not Returned \\
\hline Banks in Bauchi & $250(100 \%)$ & $229(91.6 \%)$ & $21(8.4 \%)$ \\
Total & 250 & 229 & 21 \\
\hline
\end{tabular}

Source: Surveyed Data, January, 2014.

Table 1 displayed the numbers of questionnaires that were distributed and administered to all the banks customers in which out of the distributed questionnaires 229 representing $91.6 \%$ were returned while 21 representing $8.4 \%$ were not returned.

Table 2: Electronic payment infrastructures towards an efficient cashless policy in Nigeria

\begin{tabular}{ll|llllr}
\hline Questions & SA & A & U & D & SD & TOTAL \\
\hline Electricity supply do affect e-payment transactions & 162 & 045 & 007 & 011 & 004 & 229 \\
PoS terminals are abundantly available in bauchi & 001 & 001 & 004 & 032 & 191 & 229 \\
ATM transactions are efficient and reliable & 001 & 003 & 041 & 041 & 143 & 229 \\
I do have failed transactions on mobile banking & 111 & 069 & 046 & 001 & 002 & 229 \\
Internet banking is always accessible and reliable & 011 & 008 & 009 & 024 & 177 & 229 \\
TOTAL & 286 & 126 & 107 & 109 & 517 & 1145 \\
\hline \hline
\end{tabular}

The above table shows that $162(70.3 \%)$ of the customers strongly agree that electricity supply do affect e-payment transactions, $45(19.65 \%)$ agree, $7(3 \%)$ are undecided $11(5 \%)$ disagree while the remaining $4(2 \%)$ respondents strongly disagree, which means electricity supply plays a significant role in delivering epayment vis a vis cashless policy.

$1(0.4 \%)$ of the customers strongly agree that PoS (Point of Sale) terminals are abundantly available in Bauchi, $1(0.4 \%)$ agree, $4(1.7 \%)$ are undecided 32(14\%) disagree while the remaining $191(83 \%)$ respondents strongly disagree, which means PoS terminals are not abundantly available in Bauchi which will hinder efficient cashless policy in the state.

$1(0.34 \%)$ of the customers strongly agree that ATM transactions are efficient and reliable, $3(1.3 \%)$ agree, $41(17.9 \%)$ are undecided, $41(17.9 \%)$ disagree while the remaining $143(62.4 \%)$ respondents strongly disagree, which means ATM transactions are not so reliable and efficient.

$111(48.5 \%)$ of the customers strongly agree that they do have failed transactions on mobile banking transactions, $69(30.1 \%)$ agree, $46(20.1 \%)$ are undecided, $1(0.4 \%)$ disagree while the remaining $2(0.8 \%)$ respondents strongly disagree, which means majority do have failed transactions on mobile banking transactions which is a s result of inefficient mobile network service provider.

$11(5 \%)$ of the customers strongly agree that internet banking is always accessible and reliable, $8(3.5 \%)$ agree, $9(3.9 \%)$ are undecided $24(10.5 \%)$ disagree while the remaining $177(77.3 \%)$ respondents strongly disagree, which means internet banking is not always reliable and accessible. 
Hypothesis I

\section{Testing of Hypothesis}

$\mathrm{H}_{\mathrm{o}}$ : Effective e-payment infrastructure is an essential tool for an efficient cashless policy.

Table 4: Calculation of Chi-Square for Hypothesis I

\begin{tabular}{lllll}
\hline $\mathrm{o}$ & $\mathrm{E}$ & $\mathrm{o}-\mathrm{e}$ & $(\mathrm{o}-\mathrm{e})^{2}$ & $(\mathrm{o}-\mathrm{e})^{2} / \mathrm{e}$ \\
\hline 162 & 57.2 & 104.8 & 10983.04 & 192.0 \\
045 & 25.2 & 19.8 & 392.04 & 9.69 \\
007 & 21.4 & -14.4 & 207.36 & 5.35 \\
011 & 21.8 & -10.8 & 116.64 & 95.55 \\
004 & 103.4 & -99.4 & 9880.36 & 55.22 \\
001 & 57.2 & -56.2 & 3158.44 & 23.24 \\
001 & 25.2 & -24.2 & 585.64 & 14.15 \\
004 & 21.4 & -17.4 & 302.76 & 4.77 \\
032 & 21.8 & 10.2 & 104.04 & 74.21 \\
191 & 103.4 & 87.6 & 7673.76 & 55.22 \\
001 & 57.2 & -56.2 & 3158.44 & 19.56 \\
003 & 25.2 & -22.2 & 492.84 & 17.95 \\
041 & 21.4 & 19.6 & 384.16 & 16.91 \\
041 & 21.8 & 19.2 & 368.64 & 50.17 \\
143 & 103.4 & 39.6 & 1568.16 & 76.13 \\
111 & 57.2 & 53.8 & 2894.44 & 28.28 \\
069 & 25.2 & 43.8 & 1918.44 & 19.85 \\
046 & 21.4 & 24.6 & 605.16 & 99.44 \\
001 & 21.8 & -20.8 & 432.64 & 37.32 \\
002 & 103.4 & -101.4 & 10281.96 & 11.74 \\
011 & 57.2 & -46.2 & 2134.44 & 7.19 \\
008 & 25.2 & -17.2 & 295.84 & 0.22 \\
009 & 21.4 & -12.4 & 153.76 & 52.39 \\
024 & 21.8 & 2.2 & 5.84 & 997.72 \\
177 & 103.4 & 73.6 & 5416.96 & \\
\hline
\end{tabular}

Degree of freedom $(\mathrm{v})=(\mathrm{r}-1)(\mathrm{c}-1)$

$$
\begin{aligned}
& =(5-1)(5-1) \\
& =4 \times 4 \quad=16
\end{aligned}
$$

Using the chi-square distribution table by checking the level of significance of $5 \%(0.05)$ against the degree of freedom (16)

Decision Rule:

$$
\begin{aligned}
\mathrm{X}_{\mathrm{t}}^{2} & =26.27 ; \\
\mathrm{X}_{\mathrm{c}}{ }_{\mathrm{c}} & =997.72
\end{aligned}
$$

Reject $\mathrm{H}_{\mathrm{o}}$ : if $\mathrm{X}^{2}>\mathrm{X}^{2}{ }_{\mathrm{t}}$; Accept $\mathrm{H}_{1}:$ if $\mathrm{X}_{\mathrm{c}}^{2}>\mathrm{X}^{2}{ }_{\mathrm{t}}$

Therefore accept $\mathrm{H}_{1}$, that is, Effective e-payment infrastructure is an essential tool for an efficient cashless policy.

\section{Summary of findings}

Based on the research analysis, hypothesis testing and interpretation of result, it was observed that effective e-payment infrastructure is an essential tool to achieve an efficient cashless policy in Nigeria. effective and efficient e-payment infrastructures which includes ATM, PoS terminals, Mobile banking / phone connectivity and internet banking connectivity; are very essential to achieve a cashless society, but it was noted that these infrastructures are either not abundantly available or not efficient. This study shows that these needed infrastructures are not reliable as it do fail customers even when they are needed most. Mobile banking that is aimed at covering the unbanked population too usually face network problem as a result of the inefficiency of the mobile network service providers. The same thing goes to the internet service providers; most customers have almost four networks' modems if not universal with several network sims, but yet the story of network problem is the same. Summarisingly, the e-payment infrastructure is so essential for an efficient cashless policy but they are neither sufficient nor efficient.

\section{Recommendations}

The following recommendations were suggested which if properly implemented will further enhance an efficient cashless policy in Nigeria:

1. More PoS should be deployed to Bauchi state and other states that it is not suffiently available as well as ATM to reduce long queue at ATM locations.

2. States governments should tap the benefit of Public Private Partnership in generating electricity that will be sufficient for their residents. 
3. Banks should properly maintain their ATM so that it will be more efficient for customers' use and competent staff should be deployed to the unit to minimise human error.

4. Training and re-training of bank staff is also recommended in handling the infrastructures; like ATM

5. The government through National Communications Commission (NCC) and Consumer Protection Council (CPC) should ensure that the telecommunication service providers are delivering efficient service to their customers as it has great impact on cashless policy.

\section{References}

[1]. Adena, O. \&Otaigbe, P. (2004). Electronic Payments System: Concepts, Challenges and Opportunities. Retrieved November, 17, 2013 from http://dspace.futa.edu.ng:8080/jspui/handle/123456789/2103

[2]. Alawiye-Adams, A. (2013). The cashless Nigeria project, subsequent back pedaling in the course of implementation and recent updates. Global Advanced Research Journal of Management and Business Studies. 2(1), 37-43.

[3]. Asaolu, T. O. Ayoola, T. J. \&Akinkoye, E. Y. (2011). Electronic Payment System in Nigeria: Implementation, Constraints and Solutions. Journal of Management and Society. 1(2), 16-21. Retrieved June 29, $2013 \quad$ from http://www.lautechtransportmgt.com/journal.html

[4]. Ayo, C. K. \&Ukpere, W. I. (2010).Design of a secure unified e-payment system in Nigeria: A case study. African Journal of Business Management. 4(9), 1753-1760.

[5]. Imiefoh, P. (2012). Towards Effective Implementation of Electronic Banking in Nigeria.AnInternational Multidisciplinary Journal, Ethiopia, African Research Review. 6(2), 290-300.

[6]. Nwaolisa, E. F. \&Kasio, E. G. (2012). Electronic Retail Payment Systems: User Acceptability and Payment Problems in Nigeria. Arabian Journal of Business and Management Review $\quad$ (OMAN Chapter).1(9).111-123.

[7]. Onajite, R. (2013). Nigerians are Passionate about the Cashless Policy. Retrieved October 29, $2013 \quad$ from $\begin{array}{lll}\text { http://www.thisdaylive.com/articles/onajite-nigerians-are-passionate-about } & \text { the-cashless-society/160932/ } \\ \text { Popoola, A. (2013). The challenge of Financial Infrastructure in Nigeria. Retrieved January 4, } & \text { from }\end{array}$

[8]. Popoola, A. (2013). The challenge of Financial Infrastructure in Nigeria. Retrieved January 4,
http://www.nigeriadevelopmentandfinanceforum.org/PolicyDialogue/Dialogue.aspx?E dition=101

[9]. Sanusi, L. (2013). Electronic Payment as Catalysts for Banking System Development. Retrieved January 4, 2014 from http://www.thisdaylive.com/articles/electronic-payment-as catalysts-for-banking-system-development/130537/

[10]. Tan, M. (2004). E-payment: The Digital Exchange. Singapore. Singapore University Press, NUS Publishing.

[11]. Sumanjeet, S. (2009). Emergence of Payment Systems in the age of Electronic Commerce: The State of Art, Global Journal of Business Research, 2(2) 17-36.

[12]. Zulu, B. (2006). E-payment a challenge for Africa, Access date: Sept. 2009, Available at: http://brendait.blogspot.com/2006/03/epayment-challenge-for-africa.html.

[13]. www.cenbank.org/cashless/ 